\title{
Quality of life and degree of satisfaction with surgical treatment in patients with
}

\section{dentoskeletal deformity}

Qualidade de vida e grau de satisfação com o tratamento cirúrgico em pacientes com deformidade dentoesquelética

Calidad de vida y grado de satisfacción con el tratamiento quirúrgico en pacientes con deformidad dentoesquelética

Itanielly Dantas Silveira Cruz ORCID: https://orcid.org/0000-0003-3271-4588 Federal University of Rio Grande do Norte, Brazil E-mail: itanielly.cruz@hotmail.com

Reginaldo Fernandes da Silva ORCID: https://orcid.org/0000-0002-1734-6150 Federal University of Rio Grande do Norte, Brazil E-mail: iregis.ferns@hotmail.com

Rafaela Monteiro de Araújo ORCID: https://orcid.org/0000-0001-6439-2830 Federal University of Rio Grande do Norte, Brazil

E-mail: rafaelamont@hotmail.com

José Sandro Pereira da Silva

ORCID: https://orcid.org/0000-0001-9774-7175 Federal University of Rio Grande do Norte, Brazil

E-mail: jspsilva@gmail.com

Kenio Costa de Lima

ORCID: https://orcid.org/0000-0002-5668-4398 Federal University of Rio Grande do Norte, Brazil E-mail: limke@uol.com.br

Hallissa Simplício Gomes Pereira ORCID: https://orcid.org/0000-0001-5398-6318 Federal University of Rio Grande do Norte, Brazil E-mail: hallissa@hotmail.com

\begin{abstract}
Objective: To evaluate the quality of life and degree of satisfaction of patients submitted to orthodontic-surgical treatment after orthognathic surgery. Methodology: thirty ortho-surgical patients responded two specific questionnaires (Portuguese versions) -one on quality of life (Orthognathic Quality of Life Questionnaire - OQLQ) and another on degree of satisfaction (Post-Surgical Patient Satisfaction Questionnaire - PSPSQ) - and responded to a form containing socioeconomic-educational data and post-surgical time. The associations between the independent (age, gender, civil status, educational level, family income and post-surgical time) and dependent variables (quality of life and degree of satisfaction) were submitted of the Mann-Whitney test (significance of 5\%). Spearman correlation test (significance of $5 \%$ ) was applied to analyze the relationship between the dependent variables. Results: The OQLQ had a mean of 16.17 $( \pm 19.17)$ and median of 12 , characterizing the sample with a good quality of life profile. The PSPSQ obtained a mean of $26.6( \pm 1.99)$ and median of 27 , evidencing a high degree of satisfaction after surgical treatment. There was a significant correlation between the OQLQ x PSPSQ of the moderate negative type (0.40 to 0.69$)$ and there was no significant correlation between socioeconomic-educational variables and post-surgical time with OQLQ and PSPSQ. Conclusion: The study indicated that the high satisfaction with the surgical treatment is directly related to the good quality of life presented after the treatment, demonstrating the importance of the ortho-surgical treatment.
\end{abstract}

Keywords: Orthognathic surgery; Quality of life; Orthodontics corrective; Patient satisfaction.

\section{Resumo}

Objetivo: Avaliar a qualidade de vida e o grau de satisfação de pacientes submetidos a tratamento ortodôntico-cirúrgico após cirurgia ortognática. Metodologia: Trinta pacientes orto-cirúrgicos responderam a dois questionários específicos (versão em português) - um sobre qualidade de vida (Orthognathic Quality of Life Questionnaire - OQLQ) e outro sobre grau de satisfação (Post-Surgical Patient Satisfaction Questionnaire - PSPSQ) - e responderam a um formulário contendo dados socioeconômico-educacionais e tempo pós-cirúrgico. As associações entre as variáveis independentes 
(idade, sexo, estado civil, escolaridade, renda familiar e tempo pós-cirúrgico) e variáveis dependentes (qualidade de vida e grau de satisfação) foram submetidas ao teste de Mann-Whitney (significância de 5\%). O teste de correlação de Spearman (significância de 5\%) foi aplicado para analisar a relação entre as variáveis dependentes. Resultados: O OQLQ teve média de $16.17( \pm 19.17)$ e mediana de 12 , caracterizando a amostra com bom perfil de qualidade de vida. O PSPSQ obteve média de $26.6( \pm 1.99)$ e mediana de 27 , evidenciando alto grau de satisfação após o tratamento cirúrgico. Houve correlação significativa entre o OQLQ x PSPSQ do tipo moderado negativo (0.40 a 0.69) e não houve correlação significativa entre as variáveis socioeconômico-educacionais e o tempo pós-cirúrgico com OQLQ e PSPSQ. Conclusão: $O$ estudo indicou que a alta satisfação com o tratamento cirúrgico está diretamente relacionada à boa qualidade de vida apresentada após o tratamento, demonstrando a importância do tratamento orto-cirúrgico.

Palavras-chave: Cirurgia ortognática; Qualidade de vida; Ortodontia corretiva; Satisfação do paciente.

\section{Resumen}

Objetivo: Evaluar la calidad de vida y el grado de satisfacción de los pacientes sometidos a tratamiento ortodóncicoquirúrgico después de la cirugía ortognática. Metodología: Treinta pacientes orto-quirúrgicos respondieron dos cuestionarios específicos (versión portuguesa), uno sobre calidad de vida (Orthognathic Quality of Life Questionnaire - OQLQ) y otro sobre grado de satisfacción (Post-Surgical Patient Satisfaction Questionnaire - PSPSQ) - y respondieron un formulario que contiene datos socioeconómicos-educativos y tiempo posquirúrgico. Las asociaciones entre variables independientes (edad, sexo, estado civil, educación, ingresos familiares y tiempo posquirúrgico) y variables dependientes (calidad de vida y grado de satisfacción) se sometieron a la prueba de Mann-Whitney (significancia del 5\%). Se aplicó la prueba de correlación de Spearman (significancia del 5\%) para analizar la relación entre las variables dependientes. Resultados: El OQLQ tuvo una media de $16.17( \pm 19.17)$ y una mediana de 12 , caracterizando a la muestra con un buen perfil de calidad de vida. El PSPSQ obtuvo una media de $26.6( \pm 1.99)$ y una mediana de 27, mostrando un alto grado de satisfacción tras el tratamiento quirúrgico. Hubo una correlación significativa entre el OQLQ x PSPSQ de tipo negativo moderado ( 0.40 a 0.69$)$ y no hubo correlación significativa entre las variables socioeconómicas y educativas y el tiempo posquirúrgico con OQLQ y PSPSQ. Conclusión: El estudio indicó que la alta satisfacción con el tratamiento quirúrgico está directamente relacionada con la buena calidad de vida que se presenta después del tratamiento, lo que demuestra la importancia del tratamiento orto-quirúrgico.

Palabras clave: Cirugía ortognática; Calidad de vida; Ortodoncia correctiva; Satisfacción del paciente.

\section{Introduction}

Health is "the complete state of physical, mental and social well-being" (World Health Organization, 2013; World Health Organization, 1997). This concept is related to human development and expresses the association between quality of life (QL) and health of the population. The QL is a situation experienced which offers conditions that one can live, feel, love and work in complete well-being and is an important measure of impact on health (Andrade \& Martins, 2011; Campos \& RodriguesNeto, 2008).

Regarding oral health, dentoskeletal malocclusions undeniably interfere with QL, as they negatively impact this, be it in the functional, aesthetic or social aspect (Martins et al., 2021; Cadogan \& Bennun, 2011; Posnick \& Wallace, 2008), where patients have difficulties in socializing, smiling, attending public places, have low self-esteem, disadvantages in the labor market and are more likely to suffer "bullying" (Martins et al., 2021; Batista et al., 2014; Seidl \& Zannon, 2004).

Studies have shown that the profile of facial attractiveness has a significant effect on the perception of others. Attractive people are considered more intelligent, socially competent, with a positive personality, better social interaction and receive more favorable professional evaluations (Olsen \& Inglehart, 2011). Thus, dentoskeletal malocclusions have a negative influence on facial attractiveness, since the face stands out for being an important means of communication, for its expressiveness and phonetics (Martins et al., 2021).

Many dental malocclusions can be treated in isolation by the orthodontist, without the need for surgery (Mihalik, Proffit \& Phillips, 2003). However, most skeletal malocclusions require a multidisciplinary approach to achieve absolute success in treatment, involving orthodontists, speech therapists, maxillofacial surgeons and psychologists (Martins et al., 2021; Esperão et al., 2010; Svedström-orist \& Tuomisto, 2010; Alanko \& Kiyak, 2008; Lazaridou-Terzoudi et al., 2003).

Consequently, orthognathic surgery (OS) as an adjunct to orthodontic treatment aims to reestablish a normal facial pattern in patients with unfavorable bone development of the face, since one of the main reasons for patients seeking this 
treatment is aesthetic dissatisfaction, followed by the functional and low self-esteem (Martins et al., 2021; Batista et al., 2014; Murphy et al., 2011; Alanko, Svedström-orist \& Tuomisto, 2010; Laureano Filho et al., 2005). Therefore, the degree of satisfaction with the result of OS can directly reflect on the quality of life of these patients.

Esperão et al. (2010) observed, analyzing patients with dentoskeletal malocclusion that they had different levels of QL during orthodontic-surgical treatment. Similarly, Costa et al. (2012) assessed the degree of satisfaction in patients undergoing the same therapy and observed that $80 \%$ of the patients were very satisfied with the treatment and only $20 \%$ were not very satisfied.

Thus, to measure quality of life and degree of patient satisfaction, professionals are usually restricted to clinical indicators, which have a greater focus on the functional aspect of malocclusions and are necessary to ascertain a specific dental problem. These clinical indicators have the limitation of the inability to translate the difficulties that malocclusion causes in daily life and self-esteem, making the psychosocial assessment deficient.

So, in order to fully qualify any intervention in the health area, in addition to clinical measurements, measures of importance to the patient that reflect the functional, physiological and social perceptions of their well-being are necessary. Therefore, this study aimed to verify the QL and degree of satisfaction of patients after orthognathic surgery. In addition, it was also sought to ascertain the influence of factors that interfere in this result, so that data that contribute to the implementation of measures that contemplate the resolution of such problems are produced.

\section{Methodology}

This is a cross-sectional study with a convenience sample that was submitted to the Human Research Ethics Committee of \#\#, being approved under the opinion, number \#\#\#.

A pilot study methodology was used (Doody \& Doody, 2015). For this, 30 ortho-surgical patients treated by the Oral and Maxillofacial Surgery service of the Dentistry Department of \#\#, \#\#, \#\#, \#\#, were interviewed, aged 18 to 60 years old, with a post-orthognathic surgery time of at least 60 days, considering the regression process of the post-surgical edema and the post-operative discomfort, which could interfere in the questionnaire responses. Patients who had been treated using the anticipated benefit approach or who had undergone surgical treatment less than 60 days were excluded from the study.

Patients were contacted personally in the referred service, during routine consultations. At the waiting place, after initial contact, they were invited to participate in the research, and those who agreed completed a Free and Informed Consent Form containing all necessary information regarding the study. Then, they filled out an individual form containing questions regarding socioeconomic-educational conditions and post-surgical time. The characterization of the socioeconomic-educational level was carried out according to the economic classification questionnaire used in SB-Brazil 2010.

The patients answered two specific questionnaires: one about QL [Orthognathic Quality of Life Questionnaire - OQLQ] in its translated and validated version in Portuguese (Araújo et al., 2013; Gava et al., 2013; Bortoluzzi et al., 2011) and another about degree of satisfaction [measured through the translation of the Postsurgical Patient Satisfaction Questionnaire - PSPSQ (Kiyak, Mcneill \& West, 1985)]. The interviews were conducted by a single researcher, previously trained, who delivered the questionnaires just explaining and answering questions, so that the patients filled them out individually without any interference from the evaluator.

The OQLQ contains 22 questions directing your questions to four domains: facial aesthetics (items 1, 7, 10, 11, 14), oral function (items 2 to 6), awareness of deformity (items 8, 9, 12,13) and social aspects (items 15 to 22); whose responses vary on a four-point scale, where " 1 " means "bothers little", "4" "bothers a lot" and "2" or " 3 " is between a little trouble and a lot of trouble, in addition to the "N/A "when it does not apply to the candidate or does not bother him, having a quantitative 
value of zero (0). This point scale ranges from 0 to 88 , where a lower score indicates a better quality of life and a greater worse QL, which is measured through the median of scores (Gava et al., 2013).

The PSPSQ consists of four questions directed at the degree of patient satisfaction after surgery. A 7-point scale is used as an auxiliary response tool, where " 1 " means "very dissatisfied or unlikely" and "7" corresponds to "very satisfied or probably". Their scores can vary from 4 to 28 points, and the result of satisfaction is also measured through their median (Kiyak, Mcneill $\&$ West, 1985).

The form containing personal data included answer options categorized as education level (illiterate; incomplete elementary school; complete elementary school; incomplete high school; complete high school; incomplete higher education and complete higher education), family income according to the questionnaire of economic classification used in SB-Brazil 2010 (up to $R$ \$ 250.00; from $R \$ 251$ to $R \$ 500.00$; from $R \$ 501$ to $R \$ 1,500.00$; from $R \$ 1,501.00$ to $R \$ 2,500.00$; from $R \$ 2,501.00$ to $\mathrm{R} \$ 4,500.00$; from $\mathrm{R} \$ 4,501.00$ to $\mathrm{R} \$ 9,500.00$; more than $\mathrm{R} \$ 9,500.00$ or do not know/did not answer), civil status (single; married; divorced ; separated; widowed), gender (male or female), post-surgical time ( 2 to 6 months; 7 to 12 months; 13 to 18 months; 19 to 24 months and more than 2 years) and age of the patient (not categorized).

The research database was built on the Microsoft Excel ${ }^{\circledR}$ program version 2016 (Microsoft Corporation, Redmond, USA), and the software used was the Statistical Package for Social Sciences ${ }^{\circledR}$ version 20.0 (IBM SPSS Statistics 20). To verify associations between the independent variables (age, gender, civil status, education level, family income and post-surgical time) and the dependent variables (quality of life and degree of satisfaction), the data were submitted to the Mann-Whitney test (significance of 5\%). To analyze the relationship between the dependent variables, Spearman's correlation test was applied $(p<0.05)$.

\section{Results}

Table 1 shows the sample's categorization according to socioeconomic-educational variables and post-surgical time. The sample consisted of 30 (100\%) patients with dentoskeletal malocclusion who underwent OS. The mean age of the patients was 31.6 years, ranging from 19 to 55 years, the majority being female $(60 \% ; n=18)$. In relation to civil status, the majority presented themselves without a stable union $(60 \% ; \mathrm{n}=18)$, with a degree of education, mostly, at a complete higher education level (40\%; $\mathrm{n}=12)$, with a predominance family income from $\mathrm{R} \$ 1,501.00$ to $\mathrm{R} \$ 2,500.00$ monthly $(43.3 \%$; $\mathrm{n}=13)$ and postsurgical time of 2 to 6 months ( $40 \%$; $=12$ ). 
Table 1 - Categorization of the sample according to socioeconomic-educational variables and post-surgical time.

\begin{tabular}{|c|c|c|c|}
\hline QUANTITATIVE VARIABLE & Average & Median & Standard deviation \\
\hline AGE & 31,6 & 29,6 & $\pm 9,5$ \\
\hline QUALITATIVE VARIABLES & Category & $\mathbf{n}$ & $(\%)$ \\
\hline \multirow[t]{2}{*}{ GENRE } & Male & 12 & 40,0 \\
\hline & Female & 18 & 60,0 \\
\hline \multirow[t]{2}{*}{ CIVIL STATUS } & Without stable union & 18 & 60,0 \\
\hline & Married & 12 & 40,0 \\
\hline \multirow[t]{5}{*}{ SCHOLARITY } & Complete primary education & 01 & 3,3 \\
\hline & Incomplete high school & 01 & 3,3 \\
\hline & Complete high school & 07 & 23,3 \\
\hline & Incomplete higher education & 09 & 30,0 \\
\hline & Complete higher education & 12 & 40,0 \\
\hline \multirow[t]{5}{*}{ FAMILY INCOME } & From $\mathrm{R} \$ 1.501$ to $\mathrm{R} \$ 2.500$ & 13 & 43,3 \\
\hline & From $\mathrm{R} \$ 2.500$ to $\mathrm{R} \$ 4.500$ & 09 & 30,0 \\
\hline & From $\mathrm{R} \$ 4.500$ to $\mathrm{R} \$ 9.500$ & 03 & 10,0 \\
\hline & More than $\mathrm{R} \$ 9.500$ & 03 & 10,0 \\
\hline & Don't know/didn't answer & 02 & 6,7 \\
\hline \multirow[t]{5}{*}{ POST SURGICAL TIME } & 2 to 6 months & 12 & 40,0 \\
\hline & 7 to 12 months & 07 & 23,3 \\
\hline & 13 to 18 months & 04 & 13,3 \\
\hline & 19 to 24 months & 02 & 6,7 \\
\hline & More of 24 months & 05 & 16,7 \\
\hline
\end{tabular}

Source: Authors.

The values obtained by the OQLQ, divided into its four domains, are shown in Figure 1. The OQLQ (scores 0-88) resulted in 0 and 88 points as the lowest and highest score, respectively, with a mean of $16.17( \pm 19.17)$ and median of 12 $(\mathrm{Q} 25=3.75 / \mathrm{Q} 75=22.50)$. In the four domains covered, the most frequent items were "I don't like being photographed" (facial aesthetics) - 20\% (n=6) -, "I have problems chewing" (oral function) - 16.7\% (n=5) -, "I spend a lot of time analyzing my teeth in the mirror" (deformity awareness) - 20\% (n=6) - and the item "Comments about my appearance really upset or upset me, even when I know that people are just playing" (social aspects) - 10\% (n=3). 
Figure 1 - Categorization of the sample according to the application of the OQLQ divided into its four domains: facial aesthetics, oral function, awareness of the deformity and social aspects.

FACIAL AESTHETICS

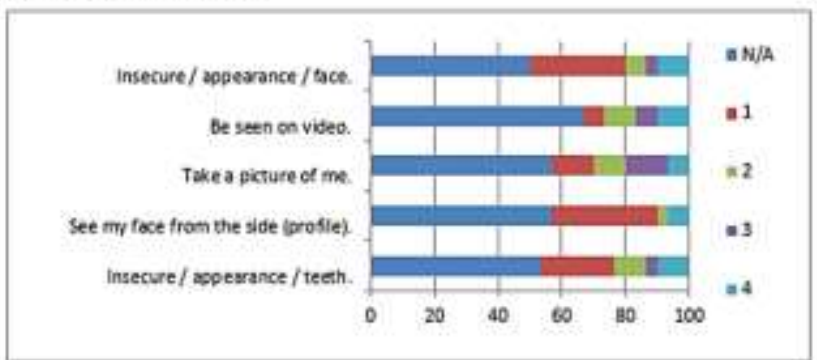

\section{AWARENESS OF THE DEFORMITY}

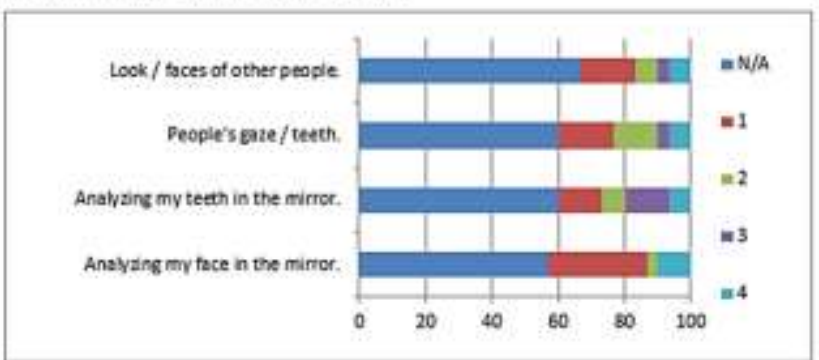

ORAL FUNCTION

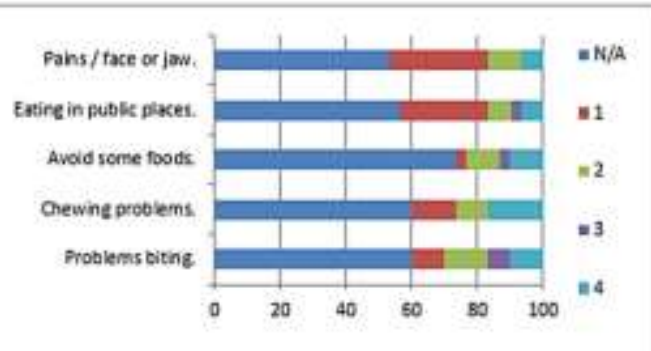

SOCIAL ASPECTS

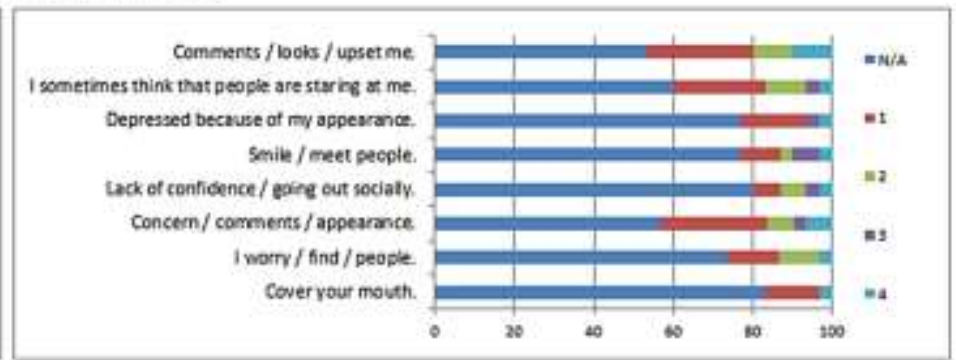

Source: Authors.

The values referring to the PSPSQ are shown in Figure 2. The PSPSQ (scores 4-28) resulted in 20 and 28 points as the lowest and highest score, respectively. He obtained an average of $26.6( \pm 1.99)$ and a median of 27 points. 46.7\% (n=14) reached the maximum score of score 28.

Figure 2 - Categorization of the sample according to the application of PSPSQ.

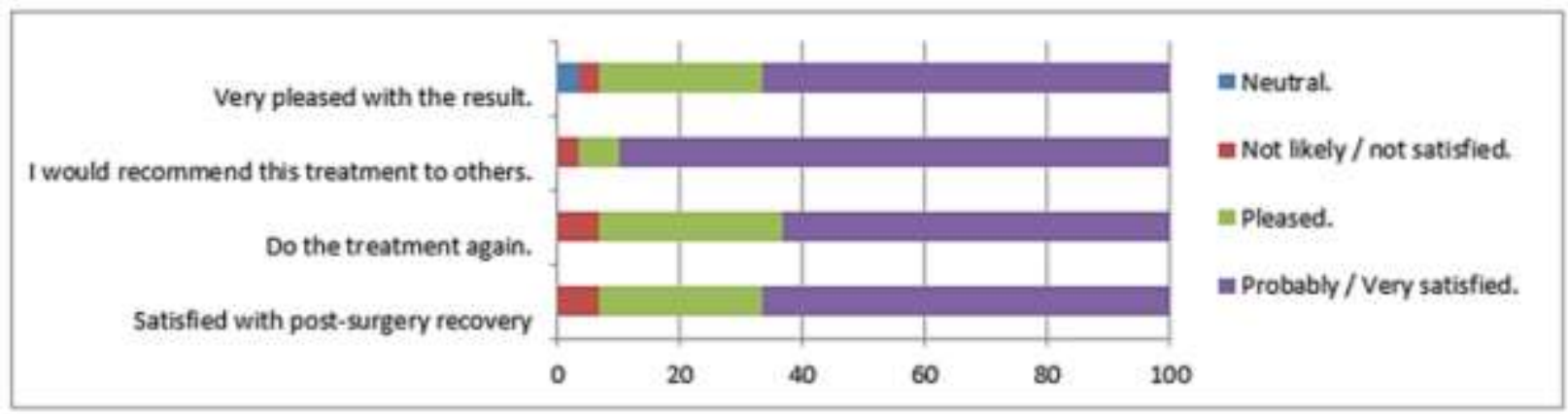

Source: Authors.

The relationship between OQLQ and PSPSQ is shown in Table 2. The correlation coefficient between OQLQ X PSPSQ was $\mathrm{CR}=-0.474$ with $p=0.008$, which means that there was a significant moderate type correlation (when the correlation coefficient varies 0.40 to 0.69 ) and negative. Only the item "I am satisfied with my post-surgery recovery" did not show a significant correlation, the others also showed a significant negative correlation. 
Research, Society and Development, v. 10, n. 3, e24410313245, 2021

(CC BY 4.0) | ISSN 2525-3409 | DOI: http://dx.doi.org/10.33448/rsd-v10i3.13245

Table 2 - Correlation between OQLQ and PSPSQ, result of the Spearman's correlation (significance of 5\%).

\begin{tabular}{|c|c|c|}
\hline & & OQLQ \\
\hline \multirow{3}{*}{ PSPSQ } & Correlation coefficient &,- 474 \\
\hline & $p$ & $.008 *$ \\
\hline & $n$ & 30 \\
\hline \multirow[t]{3}{*}{ Recovery after surgery } & Correlation coefficient &,- 229 \\
\hline & $p$ & .224 \\
\hline & $n$ & 30 \\
\hline \multirow[t]{3}{*}{ Do the treatment again } & Correlation coefficient &,- 595 \\
\hline & $p$ & $.001 *$ \\
\hline & $n$ & 30 \\
\hline \multirow[t]{3}{*}{ Would recommend to others } & Correlation coefficient &,- 446 \\
\hline & $p$ & .013 \\
\hline & $n$ & 30 \\
\hline \multirow[t]{3}{*}{ Very satisfied with the result } & Correlation coefficient &,- 497 \\
\hline & $p$ & $.005 *$ \\
\hline & $n$ & 30 \\
\hline
\end{tabular}

*Statistically significant difference at the 5\% level. Source: Authors.

The relationship between socioeconomic-educational variables and post-surgical time with OQLQ and PSPSQ are shown in Table 3. The socioeconomic-educational variables did not show significant differences between their medians, nor a significant correlation with OQLQ and PSPSQ. 
Table 3 - Comparison of median, 25th and 75th quartiles and correlation of statistical significance between OQLQ, PSPSQ and socioeconomic-educational variables and post-surgical time, result of the Mann-Whitney test (significance of 5\%).

\begin{tabular}{|c|c|c|c|c|c|c|c|}
\hline & & \multicolumn{3}{|c|}{$O Q L Q$} & \multicolumn{3}{|c|}{ PSPSQ } \\
\hline & & Median & $\mathbf{Q}_{25}-\mathbf{Q}_{75}$ & $p$ & Median & $\mathbf{Q}_{25}-\mathbf{Q}_{75}$ & $p$ \\
\hline \multirow{2}{*}{ AGE } & 19 to 30 years & 12,00 & $4,25-14,75$ & 0.739 & 27,00 & $26,00-28,00$ & 0.566 \\
\hline & 31 to 55 years & 10,00 & $0,00-36,00$ & & 28,00 & $25,50-28,00$ & \\
\hline \multirow{2}{*}{ GENRE } & Male & 5,50 & $0,75-18,25$ & 0.116 & 27,00 & $26,00-28,00$ & 0.380 \\
\hline & Female & 13,50 & $5,25-32,25$ & & 27,50 & $26,00-28,00$ & \\
\hline \multirow{2}{*}{ CIVIL STATUS } & Without stable union & 13,00 & $4,50-28,50$ & 0.640 & 27,00 & $26,00-28,00$ & 0.156 \\
\hline & With stable union & 11,00 & $0,00-20,00$ & & 28,00 & $26,00-28,00$ & \\
\hline \multirow[t]{2}{*}{ SCHOLARITY } & $\begin{array}{l}\text { Primary/High/Incomplete } \\
\text { higher }\end{array}$ & 13,00 & $4,00-21,00$ & 0.396 & 27,00 & $26,00-28,00$ & 0.875 \\
\hline & Complete higher & 6,00 & $0,00-25,00$ & & 27,00 & $26,00-28,00$ & \\
\hline \multirow{2}{*}{$\begin{array}{l}\text { FAMILY } \\
\text { INCOME }\end{array}$} & $\begin{array}{l}\text { Between } R \$ 1.500 \text { and } R \$ \\
2.500\end{array}$ & 14,00 & $6,00-21,00$ & 0.096 & 27,00 & $25,00-28,00$ & 0.771 \\
\hline & Above R\$ 2.500 & 6,00 & $0,00-24,00$ & & 27,00 & $26,00-28,00$ & \\
\hline $\begin{array}{l}\text { POST } \\
\text { SURGICAL }\end{array}$ & $\begin{array}{l}\text { Between } 2 \text { and } 6 \text { months of } \\
\text { surgery }\end{array}$ & 14,00 & $6,00-24,00$ & 0.111 & 26,00 & $24,00-27,00$ & 0.079 \\
\hline TIME & Above 6 months of surgery & 6,00 & $1,50-14,00$ & & 28,00 & $26,50-28,00$ & \\
\hline
\end{tabular}

Source: Authors.

\section{Discussion}

The sample number was minimal, $n=30$, due to the difficulty of contact with patients, since many live on other cities or are from other states, and the returns to consultations varied from weeks to months.

The mean age was 31.6 years (young-adult), ranging from 19 to 55 years of age and with a number of women (60\%; $\mathrm{n}=18$ ) higher than men, corroborating with data from some studies (Al-Ahmad et al., 2009; Sadek and Salem, 2007; Rankin et al., 1998). This can be justified due to the fact that women are more likely to be subject to glances and judgments, and to be more concerned with body image (Lee et al., 2007). Most of the interviewees presented with a state of stable non-union (60\%; $\mathrm{n}=18$ ), a factor that justifies the greater demand for this type of treatment, since these people showed a greater concern with their appearance and health (Lee et al., 2007).

Most patients had completed higher education (40\%; $\mathrm{n}=12)$ and a family income of more than $\mathrm{R} \$ 1,501.00(43.3 \%$; $\mathrm{n}=13$ ), this allows us to infer that the purchasing power and the educational or information level that patients have can influence the demand for orthodontic-surgical treatment, as this type of therapy is performed over a long term and requires a considerable financial cost.

Concerning the post-surgical time, patients with 2 to 6 months of OS prevailed $(40 \% ; n=12)$. This reflects the number of initial returns being more frequent and these patients being more accessible. The exclusion of a post-surgical phase after a few weeks is justified due to the fact that, within this period, some post-operative discomfort still remains, which could interfere with the responses to the questionnaires (Choi et al., 2010; Sadek \& Salem, 2007).

The total OQLQ scores ranged from 0 to 88 . The mean value obtained was $16.17( \pm 19.17)$ with a median of 12 $(\mathrm{Q} 25=3.75 / \mathrm{Q} 75=22.50)$. Through the evaluation of the median of the scores, it can be inferred that the sample has a good quality of life profile after OS. These results showed that ortho-surgical treatment improved oral health and had a positive impact on both function and QL, similar to what was observed in the studies by Rustemeyer and Gregersen (2012) and Esperão et al. (2010). 
Thus, orthodontic-surgical treatment is the therapy of choice for patients diagnosed with dentoskeletal malocclusion, since there is not only the gain in relation to oral health, but also to the psychosocial aspects of the patient.

Regarding the OQLQ domains, the outcome of this work also corroborates the studies by Gava et al. (2013), Murphy et al. (2011) and Al-Ahmad et al. (2009), who found that the items with the most frequent impact are facial aesthetics, oral function, deformity awareness and social aspects. In this context, Bortoluzzi et al. (2011) declare that the OQLQ scores show that "facial aesthetics" is the most important domain, affecting the patient's QL, followed by "oral function" and "social aspects of deformity". However, the authors do not mention what these average scores would be.

In relation to satisfaction with surgical treatment, $100 \%$ of the sample $(n=30)$ reported being very satisfied with it, characterizing it with a high degree of post-treatment satisfaction and showing that the patient's goals were achieved with the surgery. These results are similar to those found in the study by Costa et al., 2012, in which $80 \%$ of the patients responded that they were very satisfied and only $20 \%$ were less satisfied with the surgical treatment.

In addition, Silva et al., 2013, showed that when asked about satisfaction with the results of the surgery, 93.3\% of the patients stated that the results met their expectations. Of these, $33.3 \%$ had post-surgical complaints, and these were about recovery in the first post-surgical week, difficulty eating and maxillomandibular immobilization with rubber bands.

In most cases, post-surgical facial changes are well received, as the individual has a long-standing deformity, which is almost always congenital, so that any improvement tends to make him satisfied. Regarding the nature of the deformity, important aspects must be observed, such as the patient's perception of himself, psychosocial maturity and the patient's definition of facial alteration. This last characteristic needs to be well studied with the patient pointing out his defects and what he wants (Costa et al., 2012).

In view of the significant negative correlation of the moderate type between the OQLQ and the PSPSQ, where the lowest scores obtained in the Orthognathic Quality of Life Questionnaire were related to the highest scores in the satisfaction questionnaire, it can be concluded that the patients in this research were shown highly satisfied with surgical treatment and had a good QL after orthognathic surgery. It is inferred, therefore, that this modality of treatment promoted changes in oral health and in the psychological status of patients, consequently influencing the improvement of self-esteem and satisfaction with their facial appearance (Silva et al., 2013).

The QL and satisfaction presented after surgical treatment had no statistically significant relationship with the socioeconomic-educational variables and post-surgical time, which can be explained by the sample size and the public being relatively similar, since the questionnaires measured considerably homogeneous responses. However, there was a significant correlation between the variable "post-surgical time" and the PSPSQ. Although there is no statistically significant concrete relationship, this data is important because the sample size is minimal (30 patients). Perhaps a larger sample is needed to ascertain a possible association between these variables.

\section{Conclusion}

It was found that there is a direct relationship between high satisfaction with surgical treatment and good quality of life after a period of at least 60 days after performing orthognathic in patients with dentoskeletal malocclusions. Therefore, it can be inferred that this high degree of satisfaction and the good quality of life presented by these patients highlight the importance of the surgical procedure associated with orthodontic treatment in patients with skeletal dysplasia. Finally, it is suggested to increase the sample size for future research and studies. 


\section{Acknowledgments}

This research did not receive any specific grant from funding agencies in the public, commercial, or not-for-profit sectors.

\section{References}

Al-Ahmad, H. T., Al-Sa'di, W. S., Al-Omari, I. K., \& Al-Bitar, Z. B. (2009). Condition-specific quality of life in Jordanian patients with dentofacial deformities: a comparison of generic and diseasespecific measures. Oral Surg Oral Med Oral Pathol Oral Radiol Endod, 107(1), 4955.

Alanko, O. M., Svedström-orist, A. L., \& Tuomisto, M. T. (2010). Percepções dos pacientes de tratamento ortognática, bem-estar e estado psicológico ou psiquiátrico: Uma revisão sistemática. Acta Odontol Scand, 68(5), 249-260.

Andrade, A. I. N. P. A., \& Martins, R. M. L. (2011). Funcionalidade familiar e qualidade de vida dos idosos. Millenium, 40, 185-99.

Araújo, A. M. D., Miguel, J. A. M., Gava, E. C. B., \& Oliveira, B. H. D. (2013). Translation and cross-cultural adaptation of an instrument designed for the assessment of quality of life in orthognatic patients. Dental Press Journal of Orthodontics, 18(5), 99-106.

Batista, S. H. B., Ribeiro, E. D., Torriani, M. A., \& Aranega, A. M. (2014). Avaliação da satisfação de pacientes submetidos à cirurgia ortognática: análise qualitativa. Rev. Odontol. Araçatuba (Online), 35(2), 41-45.

Bortoluzzi, M. C., Manfro, R., Soares, I. C., \& Presta, A. A. (2011). Cross-cultural adaptation of the orthognathic quality of life questionnaire (OQLQ) in a Brazilian sample of patients with dentofacial deformities. Med Oral Patol Oral Cir Bucal, 16(5), 694-9.

Cadogan, J., \& Bennun, I. (2011). Face value: an exploration of the psychological impact of orthognathic surgery. British Journal of Oral and Maxillofacial Surgery, 49(5), 376-380.

Campos, M. O., \& Neto, J. F. R. (2008). Qualidade de vida: um instrumento para promoção de saúde. Revista Baiana de saúde pública, 32(2), $232-232$.

Choi, W. S., Lee, S., McGrath, C., \& Samman, N. (2010). Change in quality of life after combined orthodontic-surgical treatment of dentofacial deformities. Oral Surgery, Oral Medicine, Oral Pathology, Oral Radiology, and Endodontology, 109(1), 46-51.

Costa, K. L. D., Martins, L. D., Gonçalves, R. C. G., Zardo, M., \& Sá, A. C. D. D. (2012). Avaliação da qualidade de vida de pacientes submetidos à cirurgia ortognática. Revista de Cirurgia e Traumatologia Buco-maxilo-facial, 12(2), 81-92.

Doody, O., \& Doody, C. M. (2015). Conducting a pilot study: case study of a novice researcher. British Journal of Nursing, 24(21), $1074-1078$.

Esperão, P. T. G., de Oliveira, B. H., de Oliveira Almeida, M. A., Kiyak, H. A., \& Miguel, J. A. M. (2010). Oral health-related quality of life in orthognathic surgery patients. American Journal of Orthodontics and Dentofacial Orthopedics, 137(6), 790-795.

Gava, E. C. B., Miguel, J. A. M., de Araújo, A. M., \& de Oliveira, B. H. (2013). Psychometric properties of the Brazilian version of the Orthognathic Quality of Life Questionnaire. Journal of Oral and Maxillofacial Surgery, 71(10), 1762-e1.

Kiyak, H. A. (2008). Does orthodontic treatment affect patients' quality of life? Journal of dental education, 72(8), 886-894.

Kiyak, H. A., McNeill, R. W., \& West, R. A. (1985). The emotional impact of orthognathic surgery and conventional orthodontics. American journal of orthodontics, 88(3), 224-234.

Laureano Filho, J. R., Silva, E. D. D. O., Vasconcellos, R. J. D. H., Silva, L. C. F. D., \& Rocha, N. S. (2005). Alterações estéticas em discrepâncias ânteroposteriores na cirurgia ortognática. Rev. cir. traumatol. buco-maxilo-fac, 5(1), 45-52.

Lazaridou-Terzoudi, T., Kiyak, H. A., Moore, R., Athanasiou, A. E., \& Melsen, B. (2003). Long-term assessment of psychologic outcomes of orthognathic surgery. Journal of oral and maxillofacial surgery, 61(5), 545-552.

Lee, L. W., Chen, S. H., Yu, C. C., Lo, L. J., Lee, S. R., \& Chen, Y. R. (2007). Stigma, body image, and quality of life in women seeking orthognathic surgery. Plastic and reconstructive surgery, 120(1), 225-231.

Martins, F. da S., da Silva, M. F., Souza, D. S., de Farias, R. R. S., \& Ramos, P. F. C. (2021). Malocclusion and speech therapy and associated factors: integrative review. Research, Society and Development, [S. 1.], 10(1), e27610111714.

Mihalik, C. A., Proffit, W. R., \& Phillips, C. (2003). Long-term follow-up of Class II adults treated with orthodontic camouflage: a comparison with orthognathic surgery outcomes. American Journal of Orthodontics and Dentofacial Orthopedics, 123(3), 266-278.

Murphy, C., Kearns, G., Sleeman, D., Cronin, M., \& Allen, P. F. (2011). The clinical relevance of orthognathic surgery on quality of life. International journal of oral and maxillofacial surgery, 40(9), 926-930.

Olsen, J. A., \& Inglehart, M. R. (2011). Malocclusions and perceptions of attractiveness, intelligence, and personality, and behavioral intentions. American Journal of Orthodontics and Dentofacial Orthopedics, 140(5), 669-679.

Posnick, J. C., \& Wallace, J. (2008). Complex orthognathic surgery: assessment of patient satisfaction. Journal of Oral and Maxillofacial Surgery, 66(5), 934942. 
Research, Society and Development, v. 10, n. 3, e24410313245, 2021

(CC BY 4.0) | ISSN 2525-3409 | DOI: http://dx.doi.org/10.33448/rsd-v10i3.13245

Rankin, M., Borah, G. L., Perry, A. W., \& Wey, P. D. (1998). Quality-of-life outcomes after cosmetic surgery. Plastic and reconstructive surgery, 102(6), 213945 .

Rustemeyer, J., \& Gregersen, J. (2012). Quality of life in orthognathic surgery patients: post-surgical improvements in aesthetics and self-confidence. Journal of cranio-maxillofacial surgery, 40(5), 400-404.

Sadek, H., \& Salem, G. (2007). Psychological aspects of orthognathic surgery and its effect on quality of life in Egyptian patients. EMHJ-Eastern Mediterranean Health Journal, 13(1), 150-159.

Seidl, E. M. F., \& Zannon, C. M. L. D. C. (2004). Qualidade de vida e saúde: aspectos conceituais e metodológicos. Cadernos de saúde pública, 20 (2), 580-588.

Silva, A. C. A, Carvalho, R. A. S., Santos, T. S., Rocha, N. S., Gomes, A. C. A., \& Silva, E. D. O. (2013). Evaluation of life quality of patients submitted to orthognathic surgery. Dental Press Journal of Orthodontics, 18(5), 107-114.

World Health Organization. (2013). Oral health surveys: basic methods. World Health Organization.

World Health Organization. (1997). Basic epidemiological survey of oral health: Instruction Manual. World Health Organization. 